\title{
A Sustainable Development of The Law Business Friendly Environment
}

\author{
Cindawati ${ }^{1}$ \\ Faculty of the law in University Palembang. South Sumatera, Indonesia ${ }^{1}$ \\ \{cindawati_s@yahoo.com ${ }^{1}$ \}

\begin{abstract}
The purpose of the research: to analyze and explain the Development of the law business-friendly environment. The method of the research with normative juridical method. The result of the research : Consumption and production to be continue the purpose "carry out the more and more good with more little," to increase of prosperity profit to clear from activity economy with subtract to used nature resources, damage and pollution in long cycle the entire life, to relate with Balance between Human and Nature or nature resources all at once to increase quality in life. A sustainable development of the law businessfriendly environment is the effort to close everything property of the form, the resist injustice and resolve of the changing climate, in the Implementation to help achieve the development of plan in totality, subtract the cost of economy, environment, and society in the future, support the compete of economy.
\end{abstract} \\ 1 Introduction \\ Keywords: A sustainable, of the law business, friendly environment
}

The basis of balance that digs to understand, certain and application in the relationship of business, especially to result a manuscript of Contract Business International. Speaking about Basis of Balance, certain limits in the relationship with Contract Business. An agreement is in balance return, should be surrender to fair from the rightness one same other. The obligations one of the party presence on the obligations another party. The character of balance return[1] the one an agreement is a concept important to understand expediency of the change. An agreement of enjoyment and load of responsible (iusten en lasten) must share same of the average.

An agreement Sale-Buy, buyer the obligatory to pay cost of sale as a medium to get goods. Then, so that obligations seller is surrender goods, which is cost buy. Basic of the rightness for obligations one of the party can be found in the obligations one of the party, on the contrary to burden by party opponent. One upon time the party to relate with existence desire to character of balance return the mutual relationship to achieving the purpose together, length to load and content the agreement is not prohibited by constitutions and rule have strength to bind, that contract of business will be holder on the basis to balance the trick has ensure or promise that agreement of business will be fair to both the party.

The element of basis to balance, The characters and in the Relationship with Business of International. The hope objective, requisite of Balance[2] as purpose through loyalty of social, existence in material to achieve in soul to Balance. In the agreement, the important individual and society will be coincided to guarantor by law objective. The agreement from the corner substantive or aim and purpose it appears contradiction with decency and orderliness of public to must invalid for the law (nietig), and the similar of principle things will apply pleased with the agreement with the contrary to the constitutions, to clear loyalty of social is not concrete 
through the agreement so. The basis of balance to base the effort to achieve the situation of balance as a result of the appear an expropriation wealth is valid. Relate to the contents or mean the agreement, to increase to hope the party on the achievement which entrusted to him to imposed the expansion of the content of coverage or intent and the purpose. The high to hope, the more led to the expansion in principal from the scope and the quality of the obligation to the fastens himself in the agreement. The details of determinate of the contents or coverage of the agreement to occur with the way referring to the obligation to notice, research, and delivery to information that is with so that purpose will of the formed to occur in harmony with intent and the aim of the parties. From the base to think of the party know if the hope in the future to character objective or exactly to contains sacrifice of the party opponent to result, so that hope in the future is not pointed on the balance. The achievement in situation to balance the implication, in the contexts to hope in the future objective, the eforts to restrain aggrieved one of the party in the agreement.

The achievement to promise on both sides, the suppose of equality, then if there imbalance, attention will be given through equality to relate the way how to agreement the formed, and not at the end of the achievements to offered in both sides

The Basis of Balance[2] in the Law of Contract Business or Trade of International. In the contract business is the instrument to importance to the realization of the change in the form distribution goods and service. Ratio (basic of thinking) contract to refer on the purpose to occur mutation wealth in fair (gerechtvaardigde) and the show to result of the law to occur profit of the party in fair (the agreement in the principle enrichment in legal). The basis of balance in language every day to mean it word is balance (even wicht) the indicate on the meaning is "A division of the load both side in the situation of equal". A second consideration into in the realm of philosophy law trying to find answers about the idea of power bind. The basis of balance in base efforts to achieve in situation balance as result of it appears an expropriation wealth is valid. While, the Principle of the Fundamental Business International Law Contract: the basic of principle the freedom contract., the basic of principle Pacta Sunt Servanda (with plan good), the basic of principle The Settlement of Dispute through Arbitration, basic of principle the Freedom of Communication (Navigation), this freedom very essential for the implementation of trade international, and Base of Balance The Business International in the Law Contract.[3]

The harmonization with Base of Balance for the Law Contract in Trade (Business) International. The base of (harmony) is the achieve to balance between importance self and importance to relate from party opponent. Because in the contract business is the instrument to importance to the realization of the change in the form division goods and service. Ratio (basic of thinking) contract to refer on the purpose to occur mutation wealth in fair (gerechtvaardigde) and the show to result of the law to occur profit of the party in fair (the agreement in the principle enrichment in legal).

The harmonization, according to Hannu Honka is homogenized the rules or principles of substantive from Law Contract.[4, p. 31] According to Grace Xavier, to explain the reality of the Law Contract each in the country itself of Contract. While Inggris has not Law Contract in especially[5]. The harmonization of the law is efforts to find homogenize or the point of meet of the principles that are fundamental from a variety of the System of Law there is (will be harmonization). As a way to the harmonization can be done, as follows: the rule of constitutions national in field Contract, using standard contract, to apply of the Law Habit International (International Customs), the principles of the Law International (International Legal Principles), the verdict of Justice or Arbitration, harmonization according to escorts of the law and doctrine of the law. 
Can be done to the harmonization by The Institute for International Organization to character of the public, like PBB with the completeness, like UNCTAD (The United Nations Conference on International Trade of Law), UNCITRAL (The United Commission on International Trade Law), or through of the institutes regional for example, Uni Eropa. The role can be done by variety International Organization is with some things about certain of Contract. With a product to agreement or International Agreement or whatever the name is way the most to attack and way most recommendation.

According to Hannu Honka, Convention constitutes one example of the legislative method of harmonization, another type legislation. Of course. The competence for such legislation is also based on a convention (the EC Treaty) but the legislation nevertheless differs from conventions. Factual cooperation at the preparatory stages among states will result in legislative harmonization. Finally, model laws of the previously mentioned type will also to a certain extent improve harmonization even if the result of such models is highly uncertain".

The result of the work institutes of International and Regional. The efforts are PBB through the completeness, UNCITRAL [6] (The United Commission on International Trade Law) 1966, take over the task homogenize of the Law Trade International, has been issued of The United Nations Convention on Contracts for the International Sale of Goods (CISG, 1980) or convention about Law to obtain in Trade International. The purpose is creating a unification or at least harmonization of the law in field in Law Contract. ICC has been codification of clause standard contract, and Eropa has success to issued the Principles of European Contract Law (PECL). One the fact can not avoid is the existing variety of the System of Law in world it adult. The system of the law particular is Common Law, System of the Law Mixture, etc. That is System of the Law most in practice in the world is Civil Law and Common Law. The countries to practice of System of the law it is full (pure) and mixture (mixed form). Indonesia as country to follow of System Mixed ${ }^{1}$, that is Civil Law, Common Law, The Islam Law and Customs Law (local customary law). System of the law in the world has similar rules main:

a. Acknowledge Freedom of Contract (Party Autonomy);

b. Acknowledge of principle Pacta Sunt Servanda;

c. Acknowledge of principle Good Faith in the contract;

d. Acknowledge of Power Bind from Practice Habit; and

e. Acknowledge of Overmacht or impossibility of performance.

The principle Freedom of Contract (Party Autonomy)[7], Pacta Sunt Servanda, Good Faith in the contract is principle important in Law Contract International[8]. The principle of practice Habit to opinion bind to avowed in variety of System Law in the world. In the scope of law large, Article 9 (2) Konvensi CISG The (United Nations Convention on Contracts for the International Sale of Goods) acknowledge distinct power bind this habit: The parties are considered, unless otherwise agreed, to have impliedly made applicable to their contract or its formation a usage of which the parties knew and which in international trade is widely known to, and regularly observed by, parties to contract of the type involved in the particular trade concerned.

Recognition of the principle of the fifth that is overmatch or situation force has become principle recognize by System Law in general. To all thinking and creation juridical from transaction and activities business to try realization. The balance for the parties to feel fair and proper. The Basis of Balance in the Relationship with Basis and Aspect Related of Basis Balance as Basus of Ethical[2].

${ }^{1}$ Indonesia has a Mixed system 
The basis of balance in language every day to mean it word is balance (even wicht) the indicate on the meaning is "A division of the load both side in the situation of equal". A second consideration into in the realm of philosophy law trying to find answers about the idea of power bind.

This means that word "balance" on the side, to limited by the will of which is raised by consideration or situation profitable, and another side by conviction (will ability for) manifest result or cause to desire, in limited both side to reached balance can meaning positive. In or through a promise, someone in psychic (psyche) put him in a situation worth the belief that "as cause from condition to profitable" in logical will be efforts to cause right desire. Of course the desire and conviction should experienced as something that is worth or logical. This means that promise between party just will reputedly bind all the on principle the balance relationship between individual interest and public interest or the existence of a balance between the interest of both sides as each of the hope it.

The Basis of Balance as Basis of Juridical. The basis of law has function fold, that is as fundament from Law positive and as tool critical test of the system of positive law. The illustration from function fold the basis of law to given Bruggink[9] with regard to the protection of the personal living environment (de persoonlijke levenssfeer) to respect very high in the system of the law positive (Belanda). The benchmarks of the basis of law is maintained as ideals to be realized. Because of, according to Bruggink, basis of law even if it has realized can be functioned as a test tool critical to the System of Positive Law, that is if to occur that personal living environment it appears not or lack gets to protection. The basis of law "not only beneficial to solve new problems and open new fields but also need to be required as interpret and put on the rules that can never fully cover all the issues that may arise, when facing a difficult case, will be back on basis. But in the facing to apply the rule in general, the basis will play a role, even if just to reaffirm the meaning of associated or given in such a rule. With regard to the application of rules to particular cases, then to it may have found a benchmark based on the explanation and description of the rule. A criterion should be found moving from the meaning of the fact, can be tested for its relevance for contract law so that every time from the basic balance of the underlying agreement ${ }^{2}$ between the party can be raised attachment juridical decent or fair. The basis of balance, besides must have certain characteristics, should be also consistently focused on the truth of logical and adequately is concrete. Based on the consideration it development idea that Basis of Balance can be understood as basis decent or fair, and next to accept as attachment juridical in the Law Contract. Means and Purpose with The Link Point Basis Balance. In the agreement the parties to explain desire they in the form promise. Fact that people to close of Contract based on a purpose or specific intent, Fact to show the existence intertwine with indication the emergence of the agreement, to form by parties, attachment or strength to bind and fulfillment of the agreement. Through agreement, means and purpose the parties can achieve. The purpose from agreement to close of the parties and become basic for strength to bind in juridical. Besides of the strength to bind juridical, there is also attachment or power in perspective psychological (feel bind) and sociological consider of society to bind. Through of agreement can to efforts of the change with regard division and exchange goods economical although service such as a "Mutation of voluntary", there is also mutation or displacement not voluntary, such as robbing, robberly. To achievement of purpose agreement the basis of desire has explained that is the form of promises between parties to related. In the Contract Business is the instrument to importance realized of the change in the form division goods and service. Ratio (basic of

\footnotetext{
${ }^{2}$ Article 1320 Civil Code
} 
thinking) contract to refer on the purpose to occur mutation wealth in fair (gerechtvaardigde) and the show to result of the law to occur profit of the party in fair (the agreement in the principle enrichment in legal). The contract embodied in the intent and purpose of "creating situation" which better for both parties. So that exchange as enrichment to fair, can be viewed as exchange, that achievement must balance with contraprestation. An exchange in reciprocity is a key concept for the creation of justice the above. The contract has three basic purposes, as follow: First purpose, from contract is impose a promise and protect the expectation of reasonable emerging from it. Second purposes, from the contract is restrain enrichment (efforts enrich itself) that is done is not fair or not true. Third purposes is for restraining kinds of harm (to prevent certain kinds of harm). Besides of three purposes to describe above, according to Herlien Budiono, added purpose essential that is derived from the basis of (harmony), that is fourth purposes from contract is to achieve of Balance between important itself and important to relate from the party opponent. The Promise as Link Point. In the agreement, to explain desire obvious, offer and acceptance are considered as an element constitutive of the binding force of contractual. The offer and request to contain a promise. However, the existence of a promise of reciprocal not necessarily to form agreement. A new agreement is formed if there is an encounter or conformity between appointments aimed one against the other. That is true, that promise to expression of the will state, the promise given include the will and the authority to realize the promise. The importance of attitude in the form promise, that itself implies the power of bind, in the means to contain itself. The promise is a potential factor, link point real desire or duly referred to the parties in draft to assert relationship certain law (Bound on the word and deed, and the ability to make it happen). An Achievement of Balance.

The promise of individual and obligations to prevent certain kinds of harm, the implies that agreement is one of the "process' which began from an appointment to deal (free) from the parties and the end with achievement of the purpose, that is the agreement to achieve in spirit or soul of Balance. The Hope of Objective, The requisite of balance as purpose through propriety of social, existence of imaterill reached in the soul balance. In the agreement, importance of individual and society will be together to security by law objective. The agreement from corner of substantive or mean and purpose it appear to determine with morality or orderliness of public to cancel the law (nietig). And the principle, it similar will apply pleased with the agreement to determine with constitution. To clear of propriety social were intangible through the agreement so. The purpose of the research: analysis and description of the development in constitution business to knowledge environment.

For to write exciting to research with formulation of the problems:1).Are sustainable development?and 2). What is sustainable development in the law business-friendly environment?.

\section{Method}

Method of the Research: using the juridical normative method. The Purpose of the Research: an analysis and describe a sustainable development in the law business environment. 


\section{Result and Discussion}

A sustainable development[10] is the development that complies needs of the present without sacrificing the ability of future generations to comply their own needs. It contents within its two concepts:

a. The concept "needs", especially the main needs the poor in the world, the main priority must to given; and

b. The idea of limitations applied by the country of technology and social organization in the ability of the environment to comply needs of the present and future[11].

Sustainable development with Basis of Balance to base in the efforts to achieve a situation of balance as result it must appear transfer wealth invalid. With regard to the content or intent of the agreement to increase to the hope of the parties for the achievement of which entrusted to him to impose the expansion of the scope of the content or the intent and purpose. The higher the hope, the more it boils down to the expansion in principle of the scope and quality of the obligations of the parties to bind themselves in the agreement. Details of the provision the content or scope of the agreement to occurs by way of the balance between human and nature. The balance to indicate the meaning a "situation of the division of the load on either side area in a balanced".

On 1 January 2016, 17 A Sustainable Development Goals (SDGs)[12] adopted the world leaders in September 2015 a summit historic. Fifteen years to in front of with new Goals universal to obtain to all countries will be mobilization The Efforts to end everything of the form poverty, fight injustice and resolve climate change while ensuring that no one is left behind[13].

The Balance between Human and nature with the exploit of the welfare and benefit of existing on the earth, so as not abandoned. Consumption and production a sustainable is about promote resources and energy efficiency, a sustainable of infrastructure, and supply access through basic of service, green works and proper and living of quality better for them all. The implementation to help for the achievement of plan in totality, lack of economy the cost, environment, and society in future, strengthen economic competitiveness and reduce poverty. The balance between human with human, in consumption and production a sustainable of the purpose: "do more and better with less", to increase of prosperity to clear profit from activities economy with lack using resources, damage, and pollution along the whole life cycle, while improving the quality of life. It involves a variety of stakeholders, to include business, consumer, made of the police, researcher, scientist, retailer, media, and institute of the cooperation development..

\subsection{Consumer}

Requires approach systematical and cooperation between the perpetrator operates in the supply chain, from producer to consumer the end. This involves of consumer through raising education and coaching to consumer a sustainable with information, standard and label engage in public procurement sustainable[12].

A sustainable of Consumer and production important because of the implementation of framework 10 years from the program of consumer and production a sustainable. All country to develop consideration the development and ability from the developing countries. 
a. On 2020, to achieve management friendly environment ${ }^{3}$ from chemicals and all wastes along has their life cycle, in appropriate with the international framework that has been agreed, in significance to lack freedom their to air, water, and land for the minimization the impact bad through healthy of human and environment.

b. On 2030, to achieve management a sustainable and efficiency the using nature resources[13]. On 2030, divide the two per capita global leftovers food in the level of retail and consumer and reduce the loss of food together with the production and supply chain, including losses in the harvest. In substantive reduce waste through prevention, recycling and the use of the back. An encourage major companies and transnational, for the adopted practices a sustainable and for the integration information a sustainable in cycle their report. The promote of practice of the public procurement sustainable, appropriate with the policy and priority national. Make sure that people everywhere have the information relevant and awareness for sustainable development with a lifestyle that in harmony with nature. The support of countries to strengthen the capacity science and technology for the move to direct pattern more sustainable consumption and production. Development and apply the tools to monitor the impact sustainable development to tourism sustained that created the work and promote the local culture and products. Rationalizes subsidies fossil fuels that are not efficient prompted consumption of extravagant by removing distort market, appropriate with situation national, include with restructuring of tax and arrange out their subsidies dangerous, if there is for reflect ipact their environment, with fully pay attention to the special needs and conditions developing countries and minimize the impact of negative that might on the development of them in ways that protect the poor and communities affected the impact.

On 12 July 2016 The agreement international to aim ward off illegal fishing "marks the beginning of a new era: but the fast actions to need for the certain that implementation to effective, Food and Agriculture Organization (FAO). An ear of corn to save for the consumption livestock, the cost food of global to rise on June; prospect harvest wheat to strong- agency PBB, Hunger, and endurance of food, News, sustainable consumption and production.

\subsection{A Sustainable of Consumption and Production.}

Every year, it is estimated one-third of all the food is the equivalent of 1,3 milliard ton to end decompose in place rubbish from consumer and retailer, or damage because transportation and harvest of practice too bad.

a. If people around the world turn to the ball energy-saving lamps the world would save the US \$ 120 milliard every year.

b. To be the population of the global to reached 9,6 milliard in 2050, the equivalent of nearly three planets can be asked to provide natural resources needed to maintain a lifestyle today.

${ }^{3}$ Environmentally friendly management of chemicals and all wastes throughout their life cycle, in accordance with agreed international frameworks, significantly reduces their release to air, water and soil to minimize adverse impacts on human health and the environment.

${ }^{4}$ Illegal fishing is fishing that is done in violation of a law that has been established in the waters of a country. 
c. Water, less from 3 percent from freshwater in the world (drink), which 2,5 standard percent in Antarctica, North Pole, and glacier. Humanity because it must depend on 0,5 percent for all needed ecosystem and freshwater human. Human soil water faster from nature can be recycled and purify water in river and lake. More for 1 milliard people still don't have access to clean water. The use of water excessive contributing to global stress water. Free water from nature but infrastructure to needed for they convey that is expensive.

d. Energy, although progress of technology has been promoting to profit efficiency of energy, the use energy in countries of OECD will continue grow 35 percent again on 2020 Th use commercial energy and housing is region to more development quick both the use energy of the global energy after transportation. On 2002 motorcycle vehicle of the stock in countries of OECD is 550 million of vehicle ( 75 percent from private car). The rise of 32 per ownership of vehicle to hope in 2020. At the same time, kilometer of motorcycle vehicle the projected risen by 40 percent and air travel global projected to three times in the same period. Household to consumption by 29 percent energy of global and result to contribution 21 percent for the issue $\mathrm{CO} 2$ to result. Fifth for the consumption energy final in the world in 2013 is for the energy renewable.

e. Food, while the impact environment a big for food to occur on step production (agriculture, preparation of food), household influence impact through chosen diet and habit. It results influence environment through consumption energy to relationship with food and waste. 1,3 milliard ton foods wasted every year while almost 1 milliard person go malnutrition and other 1 billion hungry. An excessive of food detrimental to our health and environment. 2 milliard person in the world overweight or obesity. The land of degradation, land fertility declines, the used water is not sustainable, overfishing and degradation sea environment all the subtract ability nature resources for the supply of food. Infield food to donation about 30 percent from the total issue A Greenhouse Gas.

f. Climate change is a climate that changes due to average temperatures rising. The increase in greenhouse gas emissions in the atmosphere, specifically $\mathrm{CO} 2$, has trapped the hot temperatures in the Earth's atmosphere [14] is not a myth. All the country from PBB has acknowledged the implications dangerous it posed for not only the environment but also to the construction of human and peace and security. The need to resolve of the cause of this phenomenon and reduce the impact has become more urged considering the declaration newest by Panel Antar of government about Climate Change (IPCC). (IPCC) to clarify that temperature of global to determine for the add more of purpose 2 degree Celsius will be possible us to avoid the impact of the most dangerous of climate change. The new efforts for the society international for war on this development to catch in adoption from Agreement Paris on 12 December 2015 with A Climate Change PBB in Paris. In the countries of agreement to commitment for actions ambitious to curb the temperature is a global not exceeding 2 degree Celcius on the sign it last period.

According to Goal n.12 of the 2030 Agenda for Sustainable Development aims to ensure sustainable consumption and production patterns [15].

For the Sustainable Development to aim for the pattern ensure of consumption and sustainable production[13].

a. Paragraph 28 from 2030 the Agenda reads: The country to commitment for 2020, environment friendly reached management of chemicals and all of the whole waste life cycle the appropriate with framework international to agreed, and insignificance to reduce the liberation of them into the air, water and land for minimization of impact bad about human health and environment. 
b. Fundamental change in a way that people produce and consume goods and services. Government, international organization, in field of business and individual should be given contribution for the pattern change of consumption and production has not sustainable, include through mobilization, for all resources, the financial help, and techniques to strengthen developing countries, technology and innovative capacity for the move to more sustainable consumption and production. We encourage the implementation of 10 years to Program on the Consumption and Sustainable Production. All countries, with countries develop consider the development and ability to develop countries.

Oslo Symposium on 1994, sustainable and consumption production (SCP) is about "the use of the services and production-related, which respond to basic need and bring a better quality of life and minimize the use of natural resources and toxic materials as well as emissions of waste and pollutants over the life cycle of the service or product so as not to harm the needs of the next generation. The concept of consumption and sustainable production then recognized in the Plan of Implementation Johannesburg, to adoption in 2002 of KTT in the World About Sustainable Development (WSSD). On that occasion, the consumption and the production of sustained identified as one of three overarching to aim, and the requirements important for sustainable development, together with: the eradication of property and natural resources management in order to encourage economic and social development. It is recognized that fundamental changes to the way society in produce and consumes is very necessary, to achieve of sustainable development of global. Johannesburg Plan of Implementation also call all countries for the pattern promote of consumption and sustainable production ${ }^{5}$, with developing countries and with all countries gets benefit from process, with consideration of principles by Rio, include, between of the public principle but responsible different as to arrange in Principle 7 Declaration Rio about Environment and Development.

Next, The plan referred to in the Letter Chapter 3 Change of pattern sustainable of consumption and production for government, international organization to relevant, in field private and all big group for role play active in change pattern of consumption and production better sustainable and more special, through paragraph 15, for "encourage and promote the development of the framework 10 years program (10YFP) in support initiative regional and national for accelerate the shift about sustainable consumption and production to promote social and economic development within the carrying capacity of the ecosystem". The framework 10- years program (10YFP) in pattern consumption and production sustainable adoption in Rio +20 Conference, through paragraph 226. UNEP has been asked to serve as the secretariat of the 10YFP and the development and management a Trust Fund to support implementation SCP in countries develop and country with economy in transition.

\subsection{The Result of Research:}

Sustainable development in law business-friendly environment is the efforts to end in everything forms poverty, fight injustice and resolve climate change. It is recognized that fundamental changes to the way society produces and consumes are very necessary, to achieve development sustainable of global. The implementation to help for achieve plan development in totality, deduct the cost economic, environment and social in future, strengthen economic competitiveness and reduce poverty. Consumption and sustainable production to aim "do more and better with more little", to increase of prosperity profit clean and economic activities with deducting the useful resources, damage and pollution along the whole life cycle to relate with Balance between Human and nature or resources while improving the quality of life.

\footnotetext{
${ }^{5}$ Sustainable consumption and production aims to "do more and better with less," increasing the welfare of the net benefits of economic activity by reducing the use of resources, damage and pollution throughout the entire life cycle, relating to the Balance between Humans and nature or resources nature while improving the quality of life.
} 


\section{Conclusion}

Sustainable development is development fulfill the needs of the present without victimizing the ability of future generations to fulfill their own needs. It contains within it two concepts: Concept 'need', especially main needs the poor in the world, the main of priority should be given; and idea limitations applied by country of technology and social organization in the ability of the environment to fulfill the current and future needs.

Sustainable development in the law business-friendly environment is management friendly environment from chemicals and all wastes along their life cycle, appropriate with framework international has been agreed, in significant reduce their release to air, water and land for minimization impact bad about human health and environment. With the efforts to end all forms of poverty, fight injustice and resolve climate change, in the implementation to help achieve of plan development in totality, deduct the cost economics, environment and society in future, strengthen economic competitiveness and reduce poverty. Consumption and sustainable production to aim "do more and better with more little", to increase of prosperity profit clean and economic activities with deducting the useful resources, damage and pollution along the whole life cycle to relate with Balance between Human and nature or resources while improving the quality of life.

\section{References}

[1] M. D. Badrulzaman, Aneka Hukum Bisnis. Bandung: Alumni, 1994.

[2] H. Budiono, Asas Keseimbangan bagi Hukum Perjanjian Indonesia Hukum Perjanjian berlandaskan Asas-asas Wigati Indonesia. Bandung: PT Citra Aditya Bakti, 2006.

[3] T. L. T. Londong, Asas Ketertiban Umum dan Konvensi New York 1958. Bandung: PT Citra Aditya Bakti, 1998.

[4] H. Honka, "Harmonization of Contract Law Through International Trade A Nordic Perspective 1996," Tulane Eur. Civ. Law Forum, vol. 11, no. 111, 1996.

[5] G. Xavier, "Harmonisation of Contract Laws-Fact, or Fiction?," Constr. LAW J., vol. 20, no. 1, pp. 3-18, 2004.

[6] C. Croft, C. Kee, and J. Waincymer, "United Nations Commission on International Trade Law (UNCITRAL)," in A Guide to the UNCITRAL Arbitration Rules, Cambridge: Cambridge University Press, pp. 457-483.

[7] Y. Fu, "Freedom of Contract in The EU and China," J. Int. Commer. Law Tecnol., vol. 8, no. 4, 2013.

[8] D. N. PHAM, "From Marx to Market: The Debates on the Economic System in Vietnam's Revised Constitution," Asian J. Comp. Law, vol. 11, no. 2, pp. 263-285, Dec. 2016.

[9] J. J. H. Bruggink, Refleksi Tentang Hukum. Bandung: Citra Aditya Bakti, 1999.

[10] Wikipedia, "Sustainable development," Wikipedia. [Online]. Available: https://en.wikipedia.org/wiki/Sustainable_development.

[11] R. Barkemeyer, D. Holt, L. Preuss, and S. Tsang, "What Happened to the 'Development' in Sustainable Development? Business Guidelines Two Decades After Brundtland," Sustain. Dev., vol. 22, no. 1, pp. 15-32, Jan. 2014.

[12] J. R. Ehrenfeld, ustainability by design: A subversive strategy for transforming our consumer culture. Yale: Yale University Press, 2009. 
[13] "UNDP support to implementation of the 2030 agenda sustainable developmentUNDP support to implementation of the 2030 agenda sustainable development.".

[14] Tamamadetsu, "Perubahan iklim dan dampaknya terhadap sumberdaya air. apa pendapat agan?," Kaskus, 2016.

[15] Sustainabledevelopment, "Goal 12: Ensure sustainable consumption and production patterns," sustainabledevelopment. . 